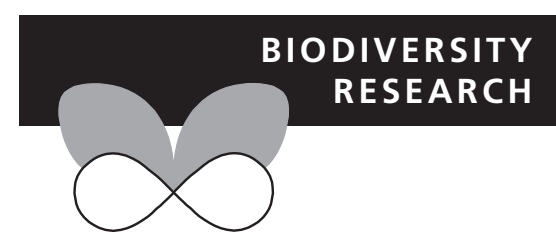

\title{
Evidence of connectivity between continental and differentiated insular populations in a highly mobile species
}

\author{
Rosa Agudo ${ }^{1{ }^{\dagger}}$, Ciro Rico ${ }^{2}$, Fernando Hiraldo ${ }^{1 \dagger}$ and José A. Donázar ${ }^{1 \dagger}$
}

\begin{abstract}
${ }^{1}$ Department of Conservation Biology, Doñana Biological Station-CSIC, Avenida Américo Vespucio s/n, E-41092 Sevilla, Spain, ${ }^{2}$ Department of Wetland Ecology, Doñana Biological Station, Avenida Américo Vespucio s/n, E-41092 Sevilla, Spain
\end{abstract}

${ }^{*}$ Correspondence: Rosa Agudo, Department of Conservation Biology, Doñana Biological Station-CSIC, Avenida Américo Vespucio s/n, E-41092 Sevilla, Spain.

E-mail: rosagudo@ebd.csic.es (http:// www.ebd.csic.es/carnivoros/personal/agudo) †http://www.ebd.csic.es/carnivoros/.

\section{ABSTRACT}

Aim Genetically differentiated insular populations are candidates for independent units for conservation. However, occasional immigration to reduced island populations may occur and potentially have important consequences in their future viability and evolutionary potential. In this study, we investigate the conservation implications of population structure and connectivity of insular and continental populations of a migratory raptor as determined using genetic tools and satellite tracking.

Location Western European populations in the Iberian Peninsula and two insular populations in the Mediterranean Sea (Balearic Islands) and Atlantic Ocean (Canary Islands).

Methods We genotyped 22 microsatellite loci in 96 Egyptian vultures (Neophron percnopterus) from the Iberian Peninsula, 36 from Menorca (Balearic archipelago) and 242 ( $85 \%$ of the current population) from Fuerteventura (Canary Islands). We analysed genetic variation to estimate structure, gene flow, genetic diversity, effective size and recent demographic history of the populations. Additionally, 19 vultures were marked with satellite transmitters to track their migration routes.

Results Insular populations were genetically differentiated from those of the mainland. We detected immigration in the insular populations and within the continental counterpart. We found similar levels of genetic variability between the continent and the islands, and a bottleneck analysis indicated recent sharp population declines in both archipelagos but not on the continent.

Main conclusions Our study provides evidence that, in spite of significant differentiation, insular populations of highly mobile species may remain connected with the mainland. Conservation programmes should take into account population connectivity and integrate differentiated units of management within complex units of conservation that can best maintain processes and potential for evolutionary change.

\section{Keywords}

Connectivity, island, microsatellites, migratory vulture, population genetics, satellite tracking.

\section{INTRODUCTION}

Understanding population structure and connectivity is crucial for determining units of management for wildlife conservation programmes (Moritz, 1994; Saccheri et al., 1998; Segelbacher \& Storch, 2002; Schtickzelle et al., 2005; Palsbøll et al., 2006; Anderson et al., 2009). Understanding processes structuring populations in environments comprised of discrete spatial units is especially challenging (Haila, 1990). The theory of island biogeography (MacArthur \& Wilson, 1967) offers a conceptual framework for the study of differentiated entities. Islands are viewed as dynamic units where immigration and extinction rates occur as functions of island area and isolation. Island isolation is thought to be subject to different spatial 
scales (Haila, 1990), which implies that immigration-extinction dynamics of geographically isolated demes may not be independent of mainland populations, especially for species with high dispersal capabilities (Whittaker \& FernándezPalacios, 2007).

Insular populations are naturally vulnerable to demographic, environmental and genetic stochastic factors associated with small populations (Pimm et al., 1988; Frankham, 1995). An inevitable consequence of small population size is the loss of genetic diversity because of genetic drift. Drift may eventually result in inbreeding depression, which also may affect the long-term persistence of a population (e.g. Lacy \& Horner, 1997, Madsen et al., 1999, Acevedo-Whitehouse et al., 2003; Liberg et al., 2005). Accordingly, higher extinction rates have been described in species endemic to islands (Frankham, 1998).

Because of the vulnerability of island populations, their isolation and their phenotypic and genotypic differentiation, insular demes have been traditionally considered as evolutionarily significant units and consequently independent units of management (Moritz, 1994; Palsbøll et al., 2006; Whittaker \& Fernández-Palacios, 2007). However, island populations of highly mobile species may receive migrant individuals from the mainland that may buffer the effects of genetic drift (Westemeier et al., 1998; Madsen et al., 1999; Frankham et al., 2002; Keller \& Waller, 2002; Marr et al., 2002; Vilà et al., 2003; Hogg et al., 2006; Ortego et al., 2008). The current study addresses the issue of connectivity between continental and insular populations by integrating genetic and satellite tracking information. These approaches are complementary, and the number of studies combining them is increasingly frequent in ecology (Bethke \& Taylor, 1996; Paetkau et al., 1999; Taylor et al., 2001; Mauritzen et al., 2002; Dearborn et al., 2003; Boulet et al., 2007). While genetic tools provide data on genetic structure, levels of migration among geographically separated populations, genetic diversity and demographic history (Haig, 1998; Schwartz et al., 2007), such methods cannot fully identify specific mechanisms that maintain connectivity among groups. In this sense, satellite tracking can reliably determine the geographical location of individuals throughout their annual cycle and thus allow estimation of the potential for gene flow among locations.

In this study, we test whether insular populations of a migratory raptor are connected to their continental counterparts, even when they are phenotypically differentiated. We employ 22 neutral genetic markers (microsatellites) and satellite tracking data to determine the genetic structure and migration of insular and continental populations. Our study model is a long-lived, highly philopatric, territorial (Grande, 2006) and migratory scavenger, the Egyptian vulture (Neophron percnopterus). This medium-sized ( $2 \mathrm{~kg}$ ) vulture inhabits dry areas of Europe, Asia and Africa (Fig. 1). It is one of the few large raptors able to colonize oceanic islands as it has carried out in the Atlantic Ocean and the Mediterranean and Arabic seas, although many of these populations are extinct (Levy, 1996; Gangoso et al., 2006; Sarà et al., 2009). Breeding birds maintain exclusive breeding territories but regularly gather in large numbers at feeding sites and communal roosts (Cramp \& Simmons, 1980; Donázar \& Ceballos, 1990). Longterm population studies have shown a low level of natal dispersal, with a median of $20 \mathrm{~km}$ (range 0-150 km; being slightly higher for females, Grande et al., 2009). Exceptional dispersals of up to $550 \mathrm{~km}$ have been detected between some Western European populations (Elorriaga et al., 2009). After

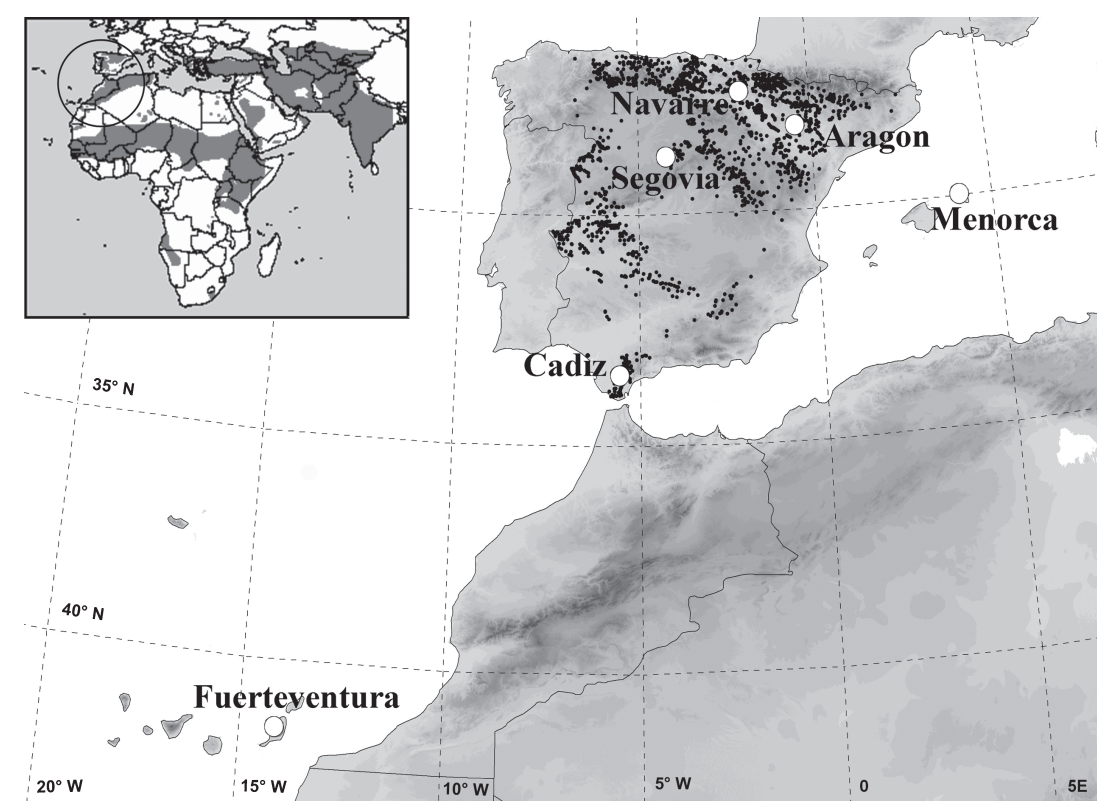

Figure 1 Distribution area of the species in the Iberian Peninsula (indicated by black spots that represent occupied territories in 2000; Del Moral, 2009) and sampling locations for this study (white spots). The map in the upper left-hand corner represents the global species' distribution. The orthographic map projection was employed. 
recruitment into breeding territories, Egyptian vultures show a low rate of breeding dispersal ( $<5 \%$ annually) and an average annual survival of 0.9 for adult birds. The generation time for the species [average ages at which females give birth to offspring (Ricklefs \& Miller, 2000)] has been estimated to be 13 years (Grande, 2006; Grande et al., 2009, authors unpublished).

Despite its broad distribution (Fig. 1), it is estimated that only 30,000-40,000 mature individuals survive in the world and the species is considered 'Endangered' (BirdLife International, 2008). In Europe, the Iberian Peninsula (Iberia) holds the bulk of the reproductive individuals but there it has also declined precipitously in recent decades, with a decrease of up to $70 \%$ in some regions during the 80 's (BirdLife International, 2008). This vulture has also suffered drastic declines on all islands including the two main insular populations remaining in Western Europe: Menorca and the Canary Islands. In the former, the number of breeding pairs was estimated to be 41 in 2002, a decline of $20 \%$ in about 10 years (De Pablo, 2002). In the Canary Islands, the population has been described as a differentiated subspecies (Neophron percnopterus majorensis) (Donázar et al., 2002a), and while abundant in the past (Martín, 1987), it has disappeared from most of the islands over the last few decades (Donázar et al., 2002b; Palacios, 2004. At present, the species is found mostly on Fuerteventura (the southeastern-most island) where it has been intensively monitored over the last 12 years (mean of 30 breeding territories/year, $\mathrm{SD}=6.4$ ). Between two and four, breeding pairs were observed every year on the closest island (Lanzarote). The population size for the Canary archipelago was estimated at about 200 birds in 2009 (authors' unpublished data).

We address whether: (1) western Palearctic populations of this species are connected, both within the continent and with respect to the insular locations, (2) the levels of genetic diversity and effective population sizes are lower in insular than mainland populations, and (3) the drastic declines in recent decades of all populations have resulted in population bottlenecks.

\section{METHODS}

\section{Sample collection}

This study was based on samples from Iberia, Menorca (Balearic Islands) and Fuerteventura (Canary Islands) (Fig. 1).

Within Iberia, we considered three different populations, previously described by Carrete et al. (2009); northern, with two subpopulations (Navarre and Aragon), central (Segovia) and southern (Cadiz). Birds were captured, ringed and sampled between 1995 and 2000 in the Iberian Peninsula (Navarre; $n=40$, Aragon; $n=19$, Cadiz; $n=22$, Segovia; $n=15)$, between 1998 and 2007 in Fuerteventura $(n=242)$ and from 1998 to 2002 in Menorca $(n=36)$. Fledglings were captured in their nests, and adult and immature birds were captured with cannon nets at supplementary feeding sites. Birds were aged by plumage (Cramp \& Simmons, 1980).

\section{Genetic analysis}

DNA extractions were performed using a standard phenolchloroform extraction (Sambrook et al., 1989). Bird's sex was determined by polymerase chain reaction (PCR) with primers 2550F and 2718R (Fridolfsson \& Ellegren, 1999) on DNA extracts from blood samples. All individuals were genotyped using five non-specific (Gautschi et al., 2000) plus 17 speciesspecific microsatellite loci (Agudo et al., 2008). All population analyses were carried out with a subsample of individuals from Fuerteventura $(N=45)$ to avoid bias because of differences in sample size. Deviations from Hardy-Weinberg and linkage equilibrium were tested using GENEPOP 3.4 (Raymond \& Rousset, 1995) followed by sequential Bonferroni correction for multiple comparisons (Rice, 1989).

\section{Population structure}

Population structure was measured using two approaches. First, pairwise population differentiation based on $F_{\mathrm{ST}}$ (Weir \& Cockerham, 1984; significance tested by 10,000 permutations) and a factorial correspondence analysis (FCA) calculated using GENETIX 4.03 (Belkhir et al., 2004). Second, we employed the Bayesian method of Pritchard et al. (2000) and Falush et al. (2003) implemented in STRUCTURE 2.1 (http:// pritch.bsd.uchicago.edu/software/structure2_1.html) to cluster individuals into respective subpopulations and reveal patterns of gene flow across populations. This program employs a Bayesian clustering to identify the most likely number of populations $(K)$ that are in Hardy-Weinberg and linkage equilibrium assuming no a priori structure.

The first step in the analysis involved estimating the number of subpopulations $(K)$. For that, we first investigated the most likely $K$ considering all sampled populations running five independent simulations of $K=1-7$. Then, we ran another five independent simulations excluding the insular individuals $(K=1-5)$ to infer cryptic population structure within the mainland. All simulations were run under standard parameters in the admixture model with the option of correlated allele frequencies at 30,000 iterations of burn-in, followed by 100,000 iterations. In both cases, the most likely value of $K$ was chosen using the $\Delta K$ statistic, based on the rate of change between successive $K$ values, as recommended by Evanno et al. (2005).

The second step of the analysis involved assigning individuals to each of the sampled subpopulations. The clustering approach used in STRUCTURE when investigating population structure can be incorporated when attempting to determine which individuals are not residents of their sampled population. When the 'usepopinfo' option of structure is employed, the program assumes an initially high probability that each individual is a resident of its sampling locality. Using prior population information allows the program to calculate posterior probabilities that individuals belong to their sampled locality/cluster. To infer migrants to the insular populations, we first ran the program with all Canary Island $(n=242)$ and all Iberian individuals as one population. Then, to detect 
migration among the continental demes, we ran the program with only the Iberian birds. For the analyses within Iberia, and given that Aragon and Segovia did not show a significant differentiation based on the $F_{\mathrm{ST}}$ values, we grouped these two locations in a single cluster. We defined individuals with $q$-values from 0.8 to 0.2 as potentially admixed (Lecis et al., 2006; Vähä \& Primmer, 2006; Bergl \& Vigilant, 2007). Burn-in and run length were the same as for runs without a priori population information.

Finally, to estimate migrants in STRUCture, we performed an exclusion test implemented in Geneclass 2.0 (Paetkau et al., 2004; Piry et al., 2004). Again, we performed the analyses clustering the individuals from Aragon and Segovia. We selected the 'detect migrants' function explicitly designed to identify first generation migrants, i.e. individuals born in a population other than the one in which they were sampled. This program uses likelihood-based statistics, in combination with resampling methods, to calculate probabilities that individuals are first generation migrants. We used two different likelihood-based test statistics to identify migrant individuals. Lh, the likelihood of finding a given individual in the population in which it was sampled, is the most appropriate statistic to use when all potential source populations have not been sampled (Paetkau et al., 2004; Piry et al., 2004). However, Lh lacks power when compared to other estimators, and thus, we also used Lh/Lmax, the ratio of Lh to the greatest likelihood among all sampled populations (Paetkau et al., 2004), which has greater power. We employed the Bayesian criterion of Rannala \& Mountain (1997) in combination with the resampling method of Paetkau et al. (2004) to determine the critical value of the test statistic (Lh or Lh/Lmax) beyond which individuals were assumed to be migrants. We selected an alpha level of 0.01 to determine critical values (Paetkau et al., 2004).

In addition, to test if the rate of gene flow within the mainland populations was influenced by geographical distance, we related genetic and geographical distances among the four locations (Navarre, Aragon, Segovia and Cadiz). We determined the geographical Universal Transverse Mercator (UTM) coordinates of the approximate distribution mid-points for each of the sampled populations, and we then calculated pairwise Euclidean distances between sites. A Mantel test with 10,000 random permutations to test significance was performed between the matrix of pairwise genetic differentiation between populations $\left[F_{\mathrm{ST}} /\left(1-F_{\mathrm{ST}}\right)\right.$, Rousset, 1997] and the matrix of the geographical distance. The analyses were performed with IBDWs (Jensen et al., 2005).

Genetic diversity, bottleneck analysis and effective population size estimates

The genetic diversity of populations was estimated using GENALEX version 6 (Peakall \& Smouse, 2006), and differences among populations were compared using Wilcoxon sign-rank tests. To detect recent population declines, we used воттLENECK (Cournet \& Luikart, 1996). This method tests for a heterozygosity excess relative to the number of alleles. It is based on the theoretical expectation that in bottlenecked populations, the number of alleles is lost more rapidly than heterozygosity decreases. We used the two-phase mutation model (TPM) allowing the default 30\% multistep mutation events, as recommended by the authors of this software in the case of microsatellite data. Effective population sizes were calculated by the linkage disequilibrium (LD) method using $\mathrm{N}_{\mathrm{E}}$ ESTIMATOR (Peel et al., 2004).

\section{Satellite tracking}

To test whether seasonal migratory movements favour the arrival of individuals to the islands, 19 Iberian Egyptian vultures were equipped with platform terminal transmitters (PTT) from 2002 to 2004. Eight of these birds were fledglings captured at nests in Cadiz, while four immature individuals of 1-, 2- and 3 years old and one fledgling were capture at supplementary feeding sites in central Iberia (Ciudad Real). The remainder of birds (one fledgling, four adults and two immature birds 1 year old) were captured at supplementary feeding sites in northern Iberian (Basque Country, Navarre and Aragon). Three individuals were not sexed, and there were 12 females and four males.

We used PTTs of two different types: 12 battery powered (PTT100, weight $45 \mathrm{~g}$ from Microwave Telemetry Inc., Columbia, MD, USA) and five 40-42 g solar PTTs (North Star Science and Technology, King George, VA, USA). They were set to an 8 -h on/120-h off duty cycle. The full transmitter equipment never exceeded 3\% of the mean body mass of fullgrown Iberian birds (1965 g, Donázar et al., 2002a). Locations were determined by means of the Argos satellite system (http:// www.argosinc.com/). Argos provides up to seven classes of locations with different degrees of accuracy. We conservatively used only those locations assigned to classes 1, 2 and 3, i.e. with accuracy < $1000 \mathrm{~m}$ (see e.g. Cadahía et al., 2005). We obtained a total of 2356 locations with this precision. To visualize locations, we employed ARCVIEw 3.2 (Hooge \& Eichenlaub, 1997), and as a cartographic base, we used Esri Data and MapsDigital Chart of the World (http://www.maproom.psu.edu/ dcw), Global Land Cover 2000 (http://www.gvm.jrc.it/glc2000/), Gtopo (http://edc.usgs.gov/products/elevation/gtopo30/gtopo30. html), and Orthorectified Lansat Enhanced Thematic Mapper (https://zulu.ssc.nasa.gov/mrsid/).

\section{RESULTS}

\section{Tests of LD and null alleles}

Significant deviations from Hardy-Weinberg equilibrium in the form of heterozygote deficits were present in loci Np238 and Np244 in all populations. These deficiencies were most likely because of non-amplifying alleles ('null alleles') at both markers, and thus, they were excluded from further analyses. Exact tests for genotypic LD confirmed the absence of physical linkage at most loci. However, some pairs of loci for a limited number of populations appeared to have significant LD (np93 
Table 1 Pairwise $F_{\mathrm{ST}}$ values between populations.

\begin{tabular}{lllllll}
\hline & CAD & ARA & NAV & SEG & MEN & FV \\
\hline CAD & - & & & & & \\
ARA & $0.025^{*}$ & - & & & & \\
NAV & $0.03^{* *}$ & $0.016^{*}$ & - & & & \\
SEG & $0.017^{\star}$ & 0.011 & $0.028^{*}$ & - & & \\
MEN & $0.095^{* *}$ & $0.078^{* *}$ & $0.085^{* *}$ & $0.079^{* *}$ & - & \\
FV & $0.114^{* *}$ & $0.103^{* *}$ & $0.104^{* *}$ & $0.11^{* *}$ & $0.144^{* *}$ & - \\
\hline
\end{tabular}

CAD, Cadiz; ARA, Aragon; NAV, Navarre; SEG, Segovia; MEN, Menorca; FV, Fuerteventura.

${ }^{\star} P<0.05 ;{ }^{*} P<0.01$.

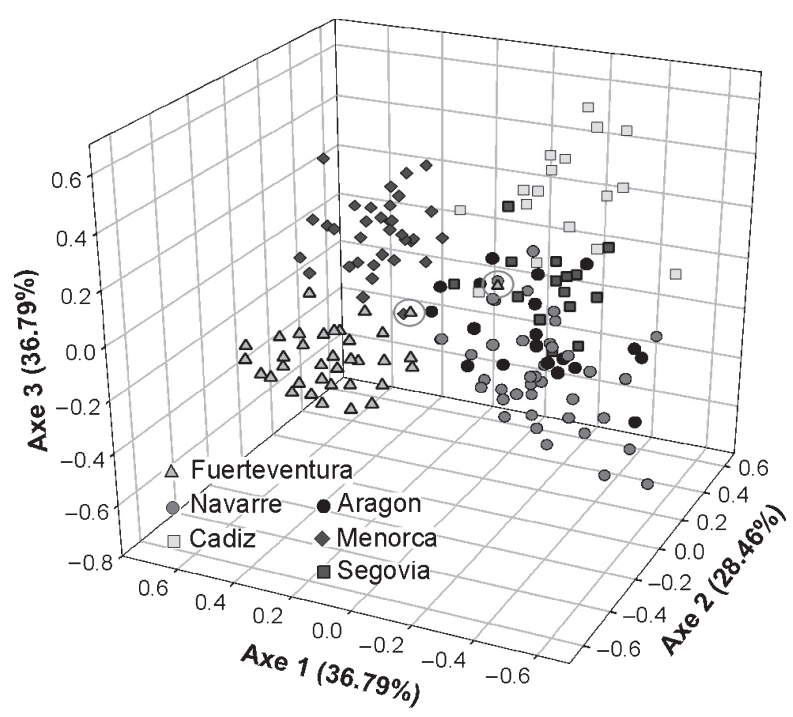

Figure 2 Scatter plot of the factorial correspondence analysis based on the allele frequencies of 22 microsatellite loci. The two insular and four continental populations are indicated. Suggested Iberian migrants found in Fuerteventura (based on the analysis in STRUCTURE and GENECLASS) are marked with a circle.

and np140 in Navarre and np244 and bv9 in Menorca; $\mathrm{P}<0.05$ after Bonferroni correction). Because no significant LD for these pairs of loci was detected elsewhere, we concluded that these loci can be treated as independent markers.

\section{Population differentiation}

Genetic differentiation across all populations measured as $F_{\mathrm{ST}}$ indicated that island populations are clearly differentiated from those on the mainland. All pairwise $F_{\mathrm{ST}}$ values were significant except between the populations from Segovia and Aragon, and the highest genetic distance was found between the two island populations (Table 1). The FCA was consistent with these results and showed the presence of one bird from Fuerteventura with a genotype compatible with continental individuals (Fig. 2).

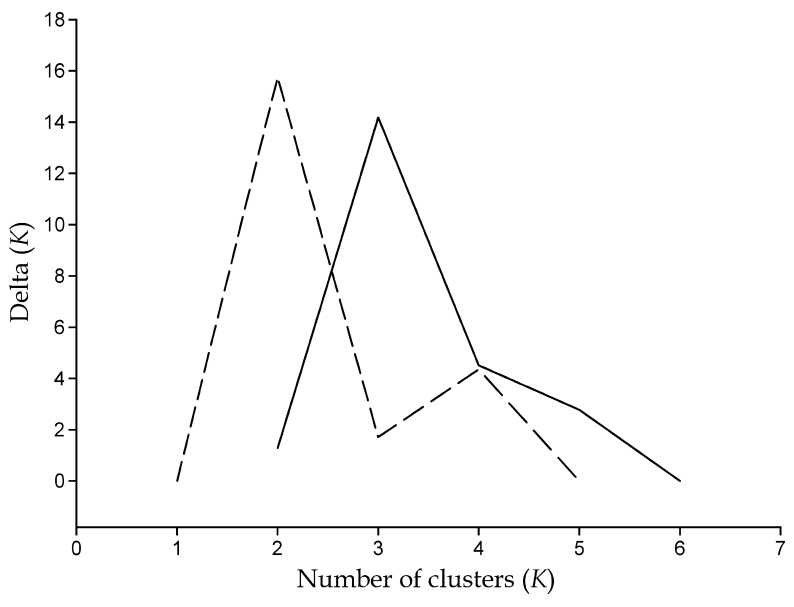

Figure 3 Rate of change in log-likelihood values [delta $(K)$ ] for estimated number of populations (Evanno et al., 2005). The maximum delta $(K)$ indicates the most likely number of clusters: within the Iberian Peninsula (excluding the insular demes, dashed line) and for all populations (solid line).

Calculation of $\Delta K$ from the STRUCTURE output produced a modal value of the statistic at $K=3$ (Figs $3 \& 4$ ). The height of the modal values of $\Delta K$ indicates the strength of the population subdivision signal (Evanno et al., 2005), suggesting deep subdivision at $K=3$. However, examination of $\operatorname{Ln} \mathrm{P}(X \mid K)$ values from the program suggested a level of subdivision at $K=4$ indicating a partial structure within the continental populations (Fig. 4). In fact, when excluding the insular populations in the structure analysis, the $\Delta K$ statistic suggested a population subdivision at $K=2$ (northern plus central and southern) (Figs 3 \& 4).

All runs at $K=3$ produced identical clustering solutions with similar values of cluster membership $q$ for all individuals within localities. Almost all individuals from the islands were assigned to their respective geographical populations with $q>0.85$, and vultures from the Iberian Peninsula were assigned to a single cluster with $q>0.84$ (Table 2). Results for $K=4$ clustered most of the southern Iberian individuals (from Cadiz) into a distinct cluster with a high probability $(q=0.8)$.

\section{Detection of migrants}

The procedures for the detection of migrants in both STRUCTURE and GENECLASs produced very similar results (Table 3). Using previously determined structure clusters as prior population information, to infer migrants to the islands $(K=3)$, struCture identified two individuals (06P and 035; probability of membership to Iberia: $q=0.96$ and 0.823 , respectively) as potential migrants, and one individual (0R6; $q=0.48$ ) of migrant ancestry in the population from Fuerteventura. GenecLass also identified one individual sampled in Menorca (539) that was assigned to its geographical origin with very low probability $(P=0.001)$ (Table 3$)$. This migrant was identified with Lh which suggests that this bird represents 


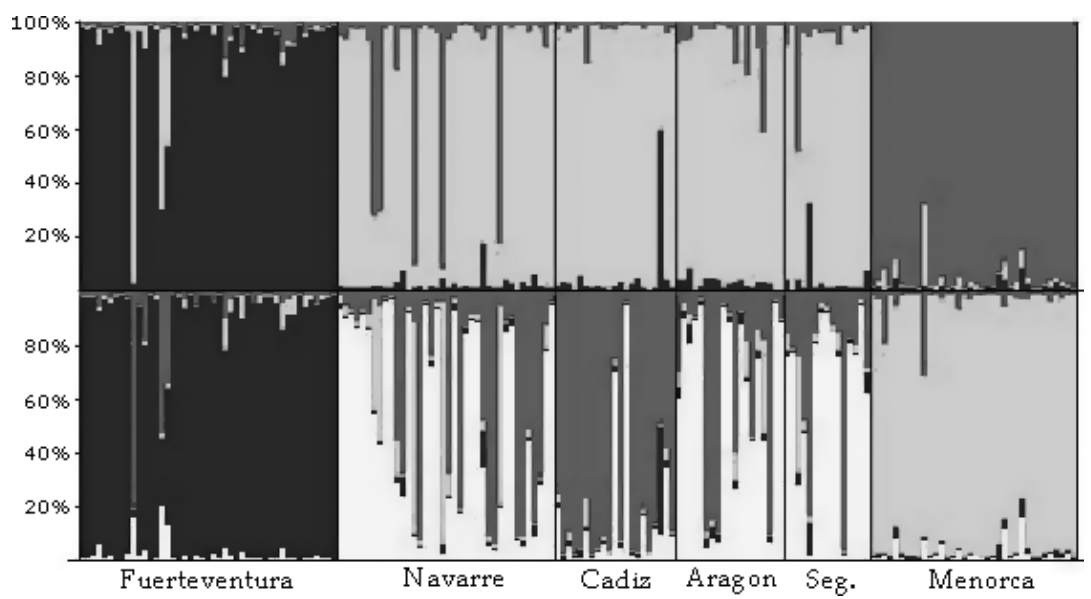

Figure 4 Clustering analysis in STRUCTURE, without prior population information, based on sample location and from $K=3$ (above) and $K=4$ (below). Each individual is represented as a colour bar, where the amount of each colour indicates the proportion of each inferred cluster. Geographical populations of origin are indicated.

Table 2 Average proportion of membership in clustering analysis of STRUCTURE, without the population information, based on sample location for $K=3$ and $K=4$.

\begin{tabular}{|c|c|c|c|c|}
\hline & \multicolumn{4}{|l|}{$k=3$} \\
\hline & $q 1$ & \multicolumn{2}{|r|}{$q 2$} & $q 3$ \\
\hline CAD & \multicolumn{2}{|l|}{0.048} & 0.93 & 0.023 \\
\hline ARA & \multicolumn{2}{|l|}{0.028} & 0.907 & 0.065 \\
\hline NAV & \multicolumn{2}{|c|}{0.023} & 0.843 & 0.134 \\
\hline SEG & \multicolumn{2}{|l|}{0.041} & 0.895 & 0.064 \\
\hline MEN & \multicolumn{2}{|l|}{0.016} & 0.028 & 0.956 \\
\hline \multirow[t]{3}{*}{ FV } & \multicolumn{2}{|l|}{0.914} & 0.063 & 0.023 \\
\hline & \multicolumn{4}{|l|}{$k=4$} \\
\hline & $q 1$ & $q 2$ & $q^{3}$ & $q 4$ \\
\hline CAD & 0.802 & 0.019 & 0.032 & 0.147 \\
\hline ARA & 0.315 & 0.051 & 0.024 & 0.61 \\
\hline NAV & 0.303 & 0.111 & 0.02 & 0.567 \\
\hline SEG & 0.269 & 0.054 & 0.025 & 0.651 \\
\hline MEN & 0.028 & 0.933 & 0.015 & 0.024 \\
\hline FV & 0.058 & 0.021 & 0.897 & 0.025 \\
\hline
\end{tabular}

Populations are CAD, Cadiz; ARA, Aragon; NAV, Navarre; SEG, Segovia; MEN, Menorca; FV, Fuerteventura.

a migrant from an unsampled area. To corroborate this finding, we performed an exclusion test in GENECLAss including the individual from Menorca (539) in the two other populations: Iberia and Fuerteventura. We obtained very low assignment probabilities for all localities (Fuerteventura $P<0.001$; Iberia $P=0.02$ and Menorca $P=0.001$ ) which provided additional evidence that this individual belonged to an unsampled source.

When using geographical sampling localities (excluding the islands and grouping Aragon and Segovia), we detected in total (using Structure and Geneclass) six potential migrants
(Table 3). However, only one individual captured in the southern location (1ML) was significantly identified as migrant by the two methods. The remainders of the suggested migrant birds by GeNECLAss were not readily classified as migrants by STRUCTURE, but not clearly assigned as residents either, suggesting that they were the products of admixture between localities.

\section{Isolation by distance within Iberia}

The Mantel test between geographical and genetic distances within Iberian subpopulations showed no significant results ( $\mathrm{Z}=-25.97, r=0.39$, one-sided $P=0.35$ from 1000 randomizations) indicating that the gene flow observed was not limited by the geographical distance between Iberian locations.

\section{Genetic diversity and inbreeding}

Values of genetic diversity are summarized in Table 4. A total of 130 alleles were detected in the six populations. Average number of alleles ranged from 3.9 to 5 (Fuerteventura and Navarre, respectively), and mean allele richness ranged from 2.42 to 3.09 (Fuerteventura and Aragon, respectively). The comparison of genetic diversity among the previously described subpopulations indicated that the northern-central Iberian subpopulation had a significantly $(P<0.01)$ higher average number of alleles $(\mathrm{Na}=5.7)$ than the southern one (Na $=4.7, P=0.01, Z=2.55)$ and the two insular demes, for which we found the lowest values (3.9 and 4.0 for Fuerteventura and Menorca, respectively, $P=0.001, Z=3.25$ in both cases). Subsequently, the number of alleles was significantly higher in the southern location than in the islands (Fuerteventura, $P=0.03, \quad Z=2.17$ and Menorca, $P=0.01$, $Z=2.43$ ). Mean allele richness was only significantly different between the northern-central subpopulation $(\mathrm{Ne}=2.99)$ and Fuerteventura $(\mathrm{Ne}=2.4) \quad(P=0.03, Z=2.13)$. Values of expected heterozygosities $\left(H_{\mathrm{E}}\right)$ were also significantly higher 
Table 3 Results of migrant detection analysis. Individuals significantly identified as potential migrants by at least one of the two approaches (implemented in Structure and Geneclass) are shown.

\begin{tabular}{|c|c|c|c|c|c|}
\hline \multirow[b]{2}{*}{ ID (ring) } & \multirow[b]{2}{*}{ Origin } & \multirow{2}{*}{$\begin{array}{l}\text { STRUCTURE } \\
q \text { (with pop. } \\
\text { information) }\end{array}$} & \multicolumn{3}{|l|}{ Geneclass } \\
\hline & & & $\begin{array}{l}\text { Migrants } F_{0} \\
{[-\log (\text { Lhome) }]}\end{array}$ & $\begin{array}{l}\text { Prob. pop. origin } \\
\text { Lh/(Lh/Lmax) }\end{array}$ & $\begin{array}{l}\text { Assigned population } \\
{[-\log (\mathrm{L})]}\end{array}$ \\
\hline \multicolumn{6}{|c|}{$K=3(\mathrm{IBE}|\mathrm{FV}| \mathrm{MEN})$} \\
\hline $06 \mathrm{P}$ & $\mathrm{FV}$ & $0.956|0.00| 0.00^{*}$ & 27.04 & $0.00 / 0.00$ & ARA (19.29) \\
\hline 035 & FV & $0.823|0.00| 0.00^{\star}$ & 19.39 & $0.017 / 0.018$ & ARA (19.35) \\
\hline 0R6 & FV & $0.479|0.474| 0.00^{*}$ & 17.74 & $0.037 / 0.028$ & CAD (17.37) \\
\hline 539 & MEN & $0.00|0.00| 0.724$ & 21.59 & $0.001 / 0.05$ & MEN (21.59) \\
\hline \multicolumn{6}{|c|}{$K=3(\mathrm{NAV}|\mathrm{CAD}| \mathrm{ARA}+\mathrm{SEG})$} \\
\hline $4 \mathrm{~F} 9$ & NAV & $0.505|0.211| 0.091$ & 20.76 & $0.017 / 0.001$ & CAD (16.71) \\
\hline $1 \mathrm{ML}$ & CAD & $0.015|0.203| 0.706^{*}$ & 23.26 & $0.002 / 0.00$ & ARA (15.86) \\
\hline 267 & SEG & $0.001|0.115| 0.710$ & 23.33 & $0.004 / 0.004$ & CAD (19.85) \\
\hline 258 & ARA & $0.002|0.322| 0.520$ & 29.09 & $0.14 / 0.001$ & CAD (14.53) \\
\hline 316 & ARA & $0.076|0.00| 0.767$ & 21.17 & $0.03 / 0.001$ & NAV (16.55) \\
\hline 323 & ARA & $0.001|0.019| 0.871$ & 19.97 & $0.04 / 0.004$ & CAD (16.75) \\
\hline
\end{tabular}

Asterisks indicate individuals significantly suggested as migrants by STRUCtURE. Populations are IBE, all Iberian populations grouped as a single cluster; FV, Fuerteventura; MEN, Menorca; NAV, Navarre; CAD, Cadiz; ARA + SEG, Aragon and Segovia grouped as a single population (based on $F_{\mathrm{ST}}$ statistics).

Table 4 Genetic diversity as: mean number of alleles $\left(N_{\mathrm{A}}\right)$, mean allelic richness $(A R)$, number of private alleles $\left(N_{\mathrm{P}}\right)$, observed and expected heterozygosities $\left(H_{\mathrm{O}}, H_{\mathrm{E}}\right)$ and inbreeding coefficient $\left(F_{\mathrm{IS}}\right)$ of Egyptian vulture populations.

\begin{tabular}{lllllllr}
\hline Pop. & $N$ & Mean $N_{\mathrm{A}}$ & Mean $A R$ & $N_{\mathrm{P}}$ & $H_{\mathrm{O}}(\mathrm{SD})$ & $H_{\mathrm{E}}(\mathrm{SD})$ & $F_{\mathrm{IS}}(95 \% \mathrm{CI})$ \\
\hline CAD & 22 & 4.7 & 2.69 & 8 & $0.55(0.23)$ & $0.55(0.20)$ & $0.022(-0.07$ to 0.03$)$ \\
ARA & 19 & 4.8 & 3.08 & 4 & $0.60(0.27)$ & $0.57(0.24)$ & $-0.013(-0.011$ to 0.02$)$ \\
NAV & 40 & 5.0 & 2.95 & 4 & $0.55(0.24)$ & $0.55(0.23)$ & $-0.004(-0.07$ to 0.02$)$ \\
SEG & 15 & 4.3 & 2.64 & 3 & $0.53(0.23)$ & $0.54(0.22)$ & $0.03(-0.08$ to 0.07$)$ \\
MEN & 36 & 4.0 & 2.59 & 2 & $0.53(0.27)$ & $0.53(0.24)$ & $-0.024(-0.09$ to 0.02$)$ \\
FV & 45 & 3.9 & 2.42 & 3 & $0.47(0.27)$ & $0.48(0.24)$ & $-0.007(-0.07$ to 0.03$)$ \\
\hline
\end{tabular}

CAD, Cadiz; ARA, Aragon; NAV, Navarre; SEG, Segovia; MEN, Menorca; FV, Fuerteventura.

in the Iberian locations (both northern-central $\left(H_{\mathrm{E}}=0.56\right)$ and southern $\left(H_{\mathrm{E}}=0.55\right)$ compared to Fuerteventura $\left(H_{\mathrm{E}}=0.47\right) \quad(P=0.01, \quad Z=2.35$ and $P=0.04, Z=1.97$, respectively), while no significant differences were found between the two insular demes. Population inbreeding coefficients $\left(F_{\text {IS }}\right)$ were positive in the populations from Cadiz, Segovia and Fuerteventura and negative in the rest, but none of them was significantly different from zero (1000 permutations) (Table 4).

\section{Bottleneck analyses and effective population sizes $\left(N_{\mathrm{e}}\right)$}

The observed proportion of heterozygotes was significantly different than expected under mutation-drift equilibrium in the two insular populations analysed (one tail for H excess: FV, $P=0.017$; MEN, $P=0.005)$, which indicated that they have suffered a recent bottleneck. We detected partially significant signs of recent population declines in northern locations and no signs of bottleneck in the central and southern locations (one tail for $\mathrm{H}$ excess: NAV, $P=0.071$; ARA, $P=0.065$; CAD, $P=0.274$ and SEG, $P=0.153$ ).

The estimations of the effective population sizes were 38.8 (95\% CI 36.1-41.7) for Fuerteventura, which closely matched the current number of successfully breeding birds (mean number of breeding pairs during the last 8 years $=35$ ) and 34.7 (95\% CI 28.9-42.6) for Menorca.

For the Iberian populations, estimations were carried out according to the observed population structure : northern and central locations together $N_{\mathrm{e}}=128.0$ (95\% CI 79.4-120.3) and the southern location $N_{\mathrm{e}}=45.5$ (95\% CI 33.7-67.1).

\section{Satellite tracking}

Information obtained from the PTTs indicated that Egyptian vultures flew over the Sahara Desert to spend the winter in the western part of the biogeographic zone known as the Sahel in southern Mauritania. Birds of different age, sex and location of origin followed similar migration routes and wintered in the same area (Fig. 5). In general, autumn movements started at 
R. Agudo et al.
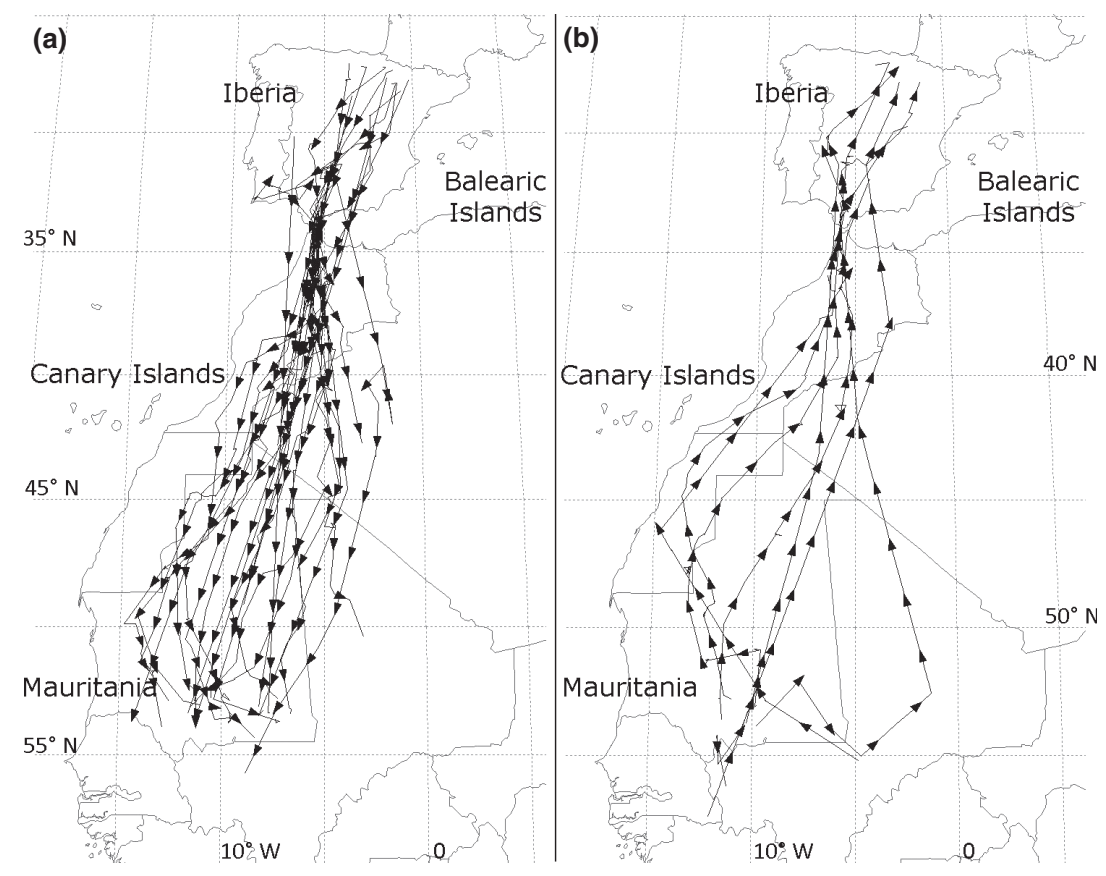

Figure 5 Migratory routes of 19 Egyptian vultures tracked with global positioning system satellite telemetry from the Iberian Peninsula to Africa during (a) autumn and (b) spring migration. The Mollweide map projection was applied.

the end of August, and birds crossed the Sahara Desert more or less in a straight line from southern Spain to the south of Mauritania (Fig. 5). We could only record spring migratory movements to the Iberian Peninsula in six cases, between the end of February to the end of May. All birds returned to the localities where they were captured. Whereas four birds followed similar routes to those in autumn, in two cases the vultures returned along the coast of West Africa. None of these birds reached the islands. We did not detect movements of individuals to the eastern Iberian coast or the Balearics.

\section{DISCUSSION}

\section{Connectivity between insular and continental populations}

We demonstrate that isolated and differentiated insular populations of highly mobile species can be connected with the continent by occasionally receiving immigrants. The genetic, morphologic and ecological differentiation indicate limited gene flow to the Egyptian vultures of the Canary Islands, demonstrating that insular birds have diverged from the European source population and adapted to the new island environment, giving rise to the present differentiated subspecies (Donázar et al., 2002a; Agudo et al., in press). On the other hand, the genetic and satellite data suggest the existence of a certain degree of connectivity between the Canary Islands and Iberia that has not masked the observed differentiation. We found two Iberian immigrants (birds 06P and 035, Table 3 ) and one bird of mixed ancestry (bird 0R6, Table 3) on Fuerteventura. Even though a correction for multiple tests should have ideally been applied to avoid type I errors, the observed convergence in the results between the two approaches confirms our findings and suggests that, although rare, admixture can occur. This finding substantiates the fact that, like many other trans-Saharan European species (Martín \& Lorenzo, 2001), Egyptian vultures occasionally reach the archipelago.

The migration routes obtained by the satellite tracking information agree with previously reported observations in other Iberian and French individuals of this species (Meyburg et al., 2004; García-Ripollés et al., 2010). All vultures from Western Europe follow similar routes across Morocco and Mauritania to overwinter in the Sahel region of Senegal, Mauritania and Mali. Spring migration routes often follow the West African coast and pass close to the Canary archipelago, $95 \mathrm{~km}$ away, which is crossable distance by the species (Cramp \& Simmons, 1980; and see García-Ripollés et al., 2010). This finding suggests that the European Egyptian vultures can easily reach the islands, as it is undoubtedly evidenced by our genetic information. In fact, other more abundant migratory species that follow similar routes are regularly observed in the archipelago (Martín \& Lorenzo, 2001).

Although our information is sparse, a similar scenario may also occur in the Balearic Islands. Our results suggest that gene flow may be limited between the Balearics and Iberia but, on the other hand, they do indicate the presence of a potential migrant (bird 539, Table 3) from an unsampled population. These are not completely unexpected results. These islands are relatively close to the continent, and many migratory birds, including large birds of prey, regularly reach the archipelago (Bannerman \& Bannerman, 1983; GOB, 2004). We would expect then that the arrival to the Balearics is favoured by 
migration. Even though the suggested immigrant has not been assigned to any of the sampled Iberian locations, we cannot exclude the possibility that it comes from an unsampled area in Iberia or from another European population (Fig. 1).

\section{Within-mainland population structure}

Observed pairwise fixation indexes within Iberia contrast with the values previously reported by Kretzman et al. (2003). In that study, the authors did not detect a significant differentiation within the Iberian locations. Although their study provided a baseline for genetically characterizing Egyptian vulture populations, it was performed with a low number of heterospecific microsatellite loci and small sample sizes. The use of a larger set of specific markers, larger sample sizes and the Bayesian approach have allowed us to obtain a more accurate characterization of the structure within Iberia. Pairwise comparison fixation indexes, PCA and Bayesian analyses indicate the existence of a population subdivision within Iberia and suggest the southern deme (Cadiz) as a genetically differentiated entity (Figs $2 \& 4$ ). This location is the most geographically isolated of the studied populations but isolation by distance (IBD) analysis revealed that its genetic differentiation cannot be explained by isolation. Instead, our results seem to support the recent fragmentation of a formerly continuous distribution of a large, panmictic population (Carrete et al., 2007). All Iberian populations have experienced drastic declines since the 80 's, decreasing as much as $70 \%$ in some regions (BirdLife International, 2008). These declines are associated with the high mortality of adults caused by poisoning, collisions with wind power turbines and electric lines and electrocution, and the loss of suitable habitats and food scarcity because of human disturbance (BirdLife International, 2008). Preventive measures should thus be taken to stop the current decline, with special attention to the southern subpopulation, and to facilitate the conservation of populations in Iberia, the main homeland of the European birds.

\section{Genetic diversity}

The genetic diversity reported in this study complements results previously obtained for this species using seven nonspecific microsatellite loci and conventional population genetics methods (Kretzman et al., 2003). Specifically, Kretzman et al., described more similar levels of $H_{\mathrm{O}}$ in Menorca (0.47) and Iberia (0.37) than with respect to Fuerteventura where genetic diversity was lower $\left(H_{\mathrm{O}}=0.31\right)$.

Our results of genetic variability are also comparable to those recently described in other long-lived vulture species (values of $H_{\mathrm{O}}$ based on microsatellites in four other species from Europe and the Middle East ranged from 0.47 to 0.67; Gouar et al., 2008; Arshad et al., 2009).

Despite the progressive decline of the species in its western distribution, our results do not seem to indicate alarmingly low levels of gene diversity. However, with respect to the insular groups, it is worth highlighting the similarities observed. The ratio of heterozygosity between insular and mainland populations $\left(H_{\mathrm{Is}} / H_{\mathrm{M}}\right)$ was 0.85 for birds from Fuerteventura and 0.95 for Menorca. While the first value is similar to the ratio found by Frankham (1997) in 27 different avian species (0.79), the ratio for Menorca is considerably higher. Accordingly, we did not detect differences in genetic diversity between Menorca and the mainland subpopulations. These similarities contrast with previous studies (see Frankham, 1997 for a review) and may be partially caused by the existence of gene flow to the insular demes.

The present population declines, and the subsequent reduction in the rate of gene flow may have serious consequences on the future genetic health and survival of these threatened insular populations, which also have very low effective population sizes $(<50)$ and are already drastically reduced. In the case of the individuals from the Canary Islands, the detected bottleneck would correspond to the welldocumented strong decline that occurred over the last few decades. It was caused by the high level of unnatural adult mortality related to human activity including poisoning, lead intoxication and electrocution (Donázar et al., 2002b; Gangoso et al., 2009). To the contrary, the Balearic population is considered to be well preserved, being the densest of the Spanish groups (one breeding pair $/ 6.7 \mathrm{~km}^{2}$ ) (Del Moral, 2009). However, our genetic results indicate that a sharp decline has affected this deme as well, that the past Balearic population was much larger and probably occupied not only Menorca but also other islands of the archipelago (Bannerman \& Bannerman, 1983). This suggestion is supported by observations of birds breeding on the island of Mallorca (Adrover, 2005).

\section{ACKNOWLEDGEMENTS}

We thank Manuel de la Riva for assistance in the field and for providing the maps and satellite images. Laura Gangoso, Angel de Pazo, Ana Trujillano, Juan José García, Agustín Velasco, Juan Manuel Grande, Ainara Cortés-Avizanda, Olga Ceballos, José Ramón Benítez, Guillermo Blanco, Jesus Lemus and Felix de Pablo helped with the field work and provided blood samples. We are grateful to Javier Juste, Carles Vilà, Jose Antonio Godoy, Severine Roques, Gary Bortolotti and other from the Molecular Ecology Lab for their interesting and helpful comments. This research was funded by the project CGL2004-00270. The Municipal Government of Fuerteventura, the Canarian Government and the Spanish Ministry of Environment provided logistic and economic support.

\section{REFERENCES}

Acevedo-Whitehouse, K., Gulland, F., Greig, D. \& Amos, W. (2003) Disease susceptibility in California sea lions. Nature, 422, 35.

Adrover, J. (2005) Contribució al coneixement de l'estatus de la moixeta voltonera Neophron percnopterus a Mallorca. Anuari ornitològic de les Balears, 20, 11-18. 
Agudo, R., Roques, S., Galarza, J.A., Rico, C., Hiraldo, F. \& Donázar, J.A. (2008) Isolation and characterization of 18 microsatellite loci in the Egyptian vulture (Neophron percnopterus). Conservation Genetics, 9, 1345-1348.

Agudo, R., Rico, C., Vilà, C., Hiraldo, F. \& Donázar, J.A. (in press) The role of humans in the diversification of a threatened island raptor. BMC Evolutionary Biology.

Anderson, B.J., Akcakaya, H.R., Araújo, M.B., Fordham, D.A., Martinez-Meyer, E., Thuiller, W. \& Brook, B.W. (2009) Dynamics of range margins for metapopulations under climate change. Proceedings of the Royal Society B: Biological Sciences, 276, 1415-1420.

Arshad, M., Pedall, I., González, J. \& Wink, M. (2009) Genetic variation of four gyps species (Gyps bengalensis, G. africanus, G. indicus and G. fulvus) based on microsatellite analysis. Journal of Raptor Research, 43, 227-236.

Bannerman, D.A. \& Bannerman, W.M. (1983) The birds of the Balearics. Croom Helm, Beckenham, UK.

Belkhir, K., Borsa, P., Chikhi, L., Raufaste, N. \& Bonhomme, F. (2004) GENETIX 4.05, logiciel sous Windows pour la génétique des populations, Laboratoire Génome, Populations, Interactions, CNRS UMR 5000, Université de Montpellier II, Montpellier.

Bergl, R.A. \& Vigilant, L. (2007) Genetic analysis reveals population structure and recent migration within the highly fragmented range of the Cross River gorilla (Gorilla gorilla diehli). Molecular Ecology, 16, 501-516.

Bethke, R. \& Taylor, M.K. (1996) Population delineation of polar bears using satellite collar data. Ecological Applications, 6, 311-317.

BirdLife International (2008) Action plan for the Egyptian Vulture Neophron percnopterus in the European Union. BirdLife International, Madrid, Spain.

Boulet, M., Couturier, S., Cote, S.D., Otto, R.D. \& Bernatchez, L. (2007) Integrative use of spatial, genetic, and demographic analyses for investigating genetic connectivity between migratory, montane, and sedentary caribou herds. Molecular Ecology, 16, 4223-4240.

Cadahía, L., Urios, V. \& Negro, J.J. (2005) Survival and movements of satellite tracked Bonelli's Eagles during their first winter. Ibis, 147, 415-419.

Carrete, M., Grande, J.M., Tella, J.L., Díaz-Delgado, R. \& Romo, A. (2007) Habitat, human pressure, and social behaviour: partialling out factors affecting large-scale territory extinction in an endangered vulture. Biological Conservation, 36, 143-154.

Carrete, M., Sánchez-Zapata, J.A., Benítez, J.R., Lobón, J. \& Donázar, J.A. (2009) Large scale risk assessment of windfarms on population viability of a globally endangered raptor. Biological Conservation, 142, 2954-2961.

Cournet, J.M. \& Luikart, G. (1996) Description and power analysis of two tests for detecting recent population bottlenecks from allele frequency data. Genetics, 144, 20012014.

Cramp, S. \& Simmons, K.E.L. (1980) The birds of the Western Palearctic, Volume II. Oxford University Press, Oxford.
De Pablo, F. (2002) La situación del alimoche Neophron percnopterus en las Islas Baleares. Anuari ornitologic de les Balears, 17, 53-57.

Dearborn, D.C., Anders, A.D., Schreiber, E.A., Adams, R.M.M. \& Mueller, U.G. (2003) Inter-island movements and population differentiation in a pelagic seabird. Molecular Ecology, 12, 2835-2843.

Del Moral, J.C. (2009) El alimoche común en España. Población reproductora en 2008 y método de censo. SEO/BirdLife, Madrid.

Donázar, J.A. \& Ceballos, O. (1990) Postfledging depedence period and development of flight and foraging behavior in the Egyptian vulture (Neophron percnopterus). Ardea, 78, 387-394.

Donázar, J.A., Negro, J.J., Palacios, C.J., Gangoso, L., Godoy, J.A., Ceballos, O., Hiraldo, F. \& Capote, N. (2002a) Description of a new subspecies of the Egyptian vulture (Accipitridae: Neophron percnopterus) from the Canary Islands. Journal of Raptor Research, 36, 17-23.

Donázar, J.A., Palacios, C.J., Gangoso, L., Ceballos, O., González, M.J. \& Hiraldo, F. (2002b) Conservation status and limiting factors of the endangered population of Egyptian Vulture (Neophron percnopterus) in the Canary Islands. Biological Conservation, 107, 89-97.

Elorriaga, J., Zuberogoitia, I., Castillo, I., Azkona, A., Hidalgo, S., Astorkia, L., Ruiz-Moneo, F. \& Iraeta, A. (2009) First documented case of long-distance, dispersal in the Egyptian vulture (Neophron percnopterus). Journal of Raptor Research, 43, 142-145.

Evanno, G., Regnaut, S. \& Goudet, J. (2005) Detecting the number of clusters of individuals using the software STRUCTURE: a simulation study. Molecular Ecology, 14, 2611-2620.

Falush, D., Stephens, M. \& Pritchard, J.K. (2003) Inference of population structure using multilocus genotype data: linked loci and correlated allele frequencies. Genetics, 164, 15671587.

Frankham, R. (1995) Inbreeding and extinction: a threshold effect. Conservation Biology, 9, 792-799.

Frankham, R. (1997) Do island populations have less genetic variation than mainland populations? Heredity, 78, 311-327.

Frankham, R. (1998) Inbreeding and extinction: island populations. Conservation Biology, 12, 665-675.

Frankham, R., Ballou, J.D. \& Briscoe, D.A. (2002) Introduction to conservation genetics. Cambridge University Press, Cambridge.

Fridolfsson, A.K. \& Ellegren, H. (1999) A simple and universal method for molecular sexing of non-ratite birds. Journal of Avian Biology, 30, 116-121.

Gangoso, L., Donázar, J.A., Scholzs, S., Palacios, C.J. \& Hiraldo, F. (2006) Contradiction in conservation of island ecosystems: plants, introduced herbivores and avian scavengers in the Canary Islands. Biodiversity and Conservation, 15, 2231-2248.

Gangoso, L., Álvarez-Lloret, P., Rodríguez-Navarro, A., Mateo, R., Hiraldo, F. \& Donázar, J.A. (2009) Long-term effects of 
lead poisoning on bone mineralization in vultures exposed to ammunition sources. Environmental Pollution, 157, 569574.

García-Ripollés, C., López-López, P. \& Urios, V. (2010) First description of migration and wintering of adult Egyptian Vultures (Neophron percnopterus) tracked by GPS satellite telemetry. Bird Study, 57, 261-265.

Gautschi, B., Tenzer, I., Müller, J.P. \& Schmid, B. (2000) Isolation and characterization of microsatellite loci in the bearded vulture (Gypaetus barbatus) and cross-amplification in three Old World vulture species. Molecular Ecology, 9, 2193-2195.

GOB (2004) Anuari Ornitològic de les Balears. GOB, Mallorca. Gouar, P., Rigal, M., Boisselier-Dubayle, C., Sarrazin, F., Arthur, C., Choisy, J.P., Hatzofe, O., Henriquet, S., Lécuyer, P., Tessier, C. \& Susic, G.S. (2008) Genetic variation in a network of natural and reintroduced populations of Griffon vulture (Gyps fulvus) in Europe. Conservation Genetics, 9, 349-359.

Grande, J.M. (2006) Effects of human activities on the demography of long-lived species; the Egyptian vulture in the Ebro valley. $\mathrm{PhD}$ Thesis, University of Sevilla, Spain.

Grande, J.M., Serrano, D., Tavecchia, G., Carrete, M., Ceballos, O., Diaz-Delgado, R., Tella, J.L. \& Donázar, J.A. (2009) Survival in a long-lived territorial migrant: effects of lifehistory traits and ecological conditions in wintering and breeding areas. Oikos, 118, 580-590.

Haig, S.M. (1998) Molecular contributions to conservation. Ecology, 79, 413-425.

Haila, Y. (1990) Towards an ecological definition of an island: a northwest European perspective. Journal of Biogeography, 17, 561-568.

Hogg, J.T., Forbes, S.H., Steele, B.M. \& bLuikart, G. (2006) Genetic rescue of an insular population of large mammals. Proceedings of the Royal Society B: Biological Sciences, 273, 1491-1499.

Hooge, P.N. \& Eichenlaub, B. (1997) Animal movement extension to Arcview. Ver. 2.0. Alaska Science Center, Biological Science Office, US Geological Survey, Anchorage, AK.

Jensen, J.L., Bohonak, A.J. \& Kelley, S.T. (2005) Isolation by distance, web service. BMC Genetics, 6, 13 (http://ibdws. sdsu.edu/).

Keller, L.F. \& Waller, D.M. (2002) Inbreeding effects in wild populations. Trends in Ecology and Evolution, 17, 230-241.

Kretzman, M.B., Capote, N., Gautschi, B., Godoy, J.A., Donázar, J.A. \& Negro, J.J. (2003) Genetically distinct island population of the Egyptian vulture (Neophron percnopterus). Conservation Genetics, 4, 697-706.

Lacy, R.C. \& Horner, B.E. (1997) Effects of inbreeding on reproduction and sex ratio of Rattus villosissimus. Journal of Mammalogy, 78, 877-887.

Lecis, R., Pierpaoli, M., Biro, Z.S., Szemethy, L., Ragni, B., Vercillo, F. \& Randi, E. (2006) Bayesian analyses of admixture in wild and domestic cats (Felis silvestris) using linked microsatellite loci. Molecular Ecology, 15, 119-131.
Levy, N. (1996) Present status, distribution and conservation trends of the Egyptian vulture (Neophron percnopterus) in the Mediterranean countries and adjacent arid regions. Biology and conservation of Mediterranean raptors (ed. by J. Muntaner and J. Mayol), pp. 13-33. Sociedad Española de Ornitología, Palma de Mallorca.

Liberg, O., Andren, H., Pedersen, H.C., Sand, H., Sejberg, D., Wabakken, P., Akesson, M. \& Bensch, S. (2005) Severe inbreeding depression in a wild wolf (Canis lupus) population. Biology Letters, 1, 17-20.

MacArthur, R.H. \& Wilson, E.O. (1967) The theory of island biogeography. Princeton University Press, Princeton.

Madsen, T., Shine, R., Olsson, M. \& Wittzell, H. (1999) Restoration of an inbred adder population. Nature, 402, 34-35.

Marr, A.B., Keller, L.F. \& Arcese, P. (2002) Heterosis and outbreeding depression in descendants of natural immigrants to an inbred population of song Sparrows (Melospiza melodia). Evolution, 56, 131-142.

Martín, A. (1987) Atlas de las aves nidificantes en la isla de Tenerife. Instituto de Estudios Canarios, Santa Cruz de Tenerife.

Martín, A. \& Lorenzo, J.A. (2001) Aves del archipiélago Canario (ed. by F. Lemus). La Laguna, Santa Cruz de Tenerife, España.

Mauritzen, M., Derocher, A.E., Wiig, Ã.y., Belikov, S.E., Boltunov, A.N., Hansen, E. \& Garner, G.W. (2002) Using satellite telemetry to define spatial population structure in Polar Bears in the Norwegian and Western Russian Arctic. Journal of Applied Ecology, 39, 79-90.

Meyburg, B.U., Gallardo, M., Meyburg, C. \& Dimitrova, E. (2004) Migrations and sojourn in Africa of Egyptian vultures (Neophron percnopterus) tracked by satellite. Journal of Ornithology, 145, 273-280.

Moritz, C. (1994) Defining 'evolutionarily significant units' for conservation. Trends in Ecology and Evolution, 9, 373-375.

Ortego, J., Aparicio, J.M., Cordero, P.J. \& Calabuig, G. (2008) Individual genetic diversity correlates with the size and spatial isolation of natal colonies in a bird metapopulation. Proceedings of the Royal Society B: Biological Sciences, 275, 2039-2047.

Paetkau, D., Amstrup, S.C., Born, E.W., Calvert, W., Derocher, A.E., Garner, G.W., Messier, F., Stirling, I., Taylor, M.K., Wiig, O. \& Strobeck, C. (1999) Genetic structure of the world's polar bear populations. Molecular Ecology, 8, 15711584 .

Paetkau, D., Slade, R., Burden, M. \& Estoup, A. (2004) Genetic assignment methods for the direct, real-time estimation of migration rate: a simulation based exploration of accuracy and power. Molecular Ecology, 13, 55-65.

Palacios, C.J. (2004) Current status and distribution of birds of prey in the Canary Islands. Bird Conservation International, 14, 203-213.

Palsbøll, P.J., Bérubé, M. \& Allendorf, F.W. (2006) Identification of management units using population genetic data. Trends in Ecology and Evolution, 22, 12-16. 
Peakall, R. \& Smouse, P.E. (2006) Genalex 6, genetic analysis in Excel. Population genetic software for teaching and research. Molecular Ecology Notes, 6, 288-295.

Peel, D., Ovenden, J.R. \& Peel, S.L. (2004) NeEstimator: version 1.3. Queensland Government, Department of Primary Industries and Fisheries, Brisbane.

Pimm, S.L., Jones, H.L. \& Diamond, J. (1988) On the risk of ectinction. American Naturalist, 132, 757-785.

Piry, S., Alapetite, A., Cornuet, J.M., Paetkau, D., Baudouin, L. \& Estoup, A. (2004) GENECLASS2: a software for genetic assignment and first-generation migrant detection. Journal of Heredity, 95, 536-539.

Pritchard, J.K., Stephens, M. \& Donnelly, P. (2000) Inference of population structure using multilocus genotype data. Genetics, 155, 945-959.

Rannala, B. \& Mountain, J.L. (1997) Detecting immigration by using multilocus genotypes. Proceedings of the National Academy of Sciences USA, 94, 9197-9201.

Raymond, M. \& Rousset, F. (1995) Testing heterozygotes excess and deficiency. Genetics, 140, 1413-1419.

Rice, W.R. (1989) Analyzing tables of statistical tests. Evolution, 43, 223-225.

Ricklefs, R.E. \& Miller, G.L. (2000) Ecology, 4th edn. Freeman, New York.

Rousset, F. (1997) Genetic differentiation and estimation of gene flow from FStatistics under isolation by distance. Genetics, 145, 1219-1228.

Saccheri, I., Kuussaari, M., Kankare, M., Vikman, P., Fortelius, W. \& Hanski, I. (1998) Inbreeding and extinction in a butterfly metapopulation. Nature, 392, 491-494.

Sambrook, J., Fritsch, E.F. \& Maniatis, T. (1989) Molecular cloning: a laboratory manual, 2nd edn. Cold Spring Harbor Laboratory Press, New York.

Sarà, M., Grenci, S. \& Di Vittorio, M. (2009) Status of Egyptian vulture (Neophron percnopterus) in Sicily. Journal of Raptor Research, 43, 66-69.

Schtickzelle, N., Choutt, J., Goffart, P., Fichefet, V. \& Baguette, M. (2005) Metapopulation dynamics and conservation of the marsh fritillary butterfly: population viability analysis and management options for a critically endangered species in Western Europe. Biological Conservation, 126, 569-581.

Schwartz, M.K., Luikart, G. \& Waples, R.S. (2007) Genetic monitoring as a promising tool for conservation and management. Trends in Ecology and Evolution, 22, 25-33.

Segelbacher, G. \& Storch, I. (2002) Capercaillie in the Alps: genetic evidence of metapopulation structure and population decline. Molecular Ecology, 11, 1669-1677.

Taylor, M.K., Akeeagok, S., Andriashek, D., Barbour, W., Born, E.W., Calvert, W., Cluff, H.D., Ferguson, S., Laake, J. \&
Rosing-Asvid, A. (2001) Delineating Canadian and Greenland polar bear (Ursus maritimus) populations by cluster analysis of movements. Canadian Journal of Zoology, 79, 690-709.

Vähä, J.P. \& Primmer, C.R. (2006) Efficiency of model-based Bayesian methods for detecting hybrid individuals under different hybridization scenarios and with different numbers of loci. Molecular Ecology, 15, 63-72.

Vilà, C., Sundqvist, A., Flagstad, Ø., Seddon, J., Björnerfeldt, S., Kojola, I., Casulli, A., Sand, H., Wabakken, P. \& Ellegren, H. (2003) Rescue of a severely bottlenecked wolf (Canis lupus) population by a single immigrant. Proceedings of the Royal Society B: Biological Sciences, 270, 91-97.

Weir, B.S. \& Cockerham, C.C. (1984) Estimating F-statistics for the analysis of population structure. Evolution, 38, 13581370 .

Westemeier, R.L., Brawn, J.D., Simpson, S.A., Esker, T.L., Jansen, R.W., Walk, J.W., Kershner, E.L., Bouzat, J.L. \& Paige, K.N. (1998) Tracking the long-term decline and recovery of an isolated population. Science, 282, 1695-1698.

Whittaker, R.J. \& Fernández-Palacios, J.M. (2007) Island biogeography. Ecology, evolution and conservation. Oxford University Press, Oxford.

\section{BIOSKETCH}

The authors form part of a multidisciplinary research group (evolutionary ecology, behavioural ecology, spatial population ecology, interactions, demography and population dynamics, extinction patterns and conservation genetics) aimed at building the scientific basis needed for the conservation of biological diversity in all its forms. It is oriented towards threatened ecosystems, communities, species and populations.

The main scientific interest of the first author is conservation genetics of threatened vertebrates with a special interest in insular communities. She works with both neutral markers and functional genes (MHC genes) and is interested in answering questions at two different levels; at the population level: population genetic diversity, structure, historical demography or local adaptation, and at the individual level: relationship of genetic diversity, inbreeding and parentage with mate choice, fitness and social behaviour. She is especially interested in the consequences of intrapopulation heterogeneity on the viability and conservation of populations.

Editor: David Green 